\title{
Sources of funds and investment activities of venture capital funds: evidence from Germany, Israel, Japan and the United Kingdom
}

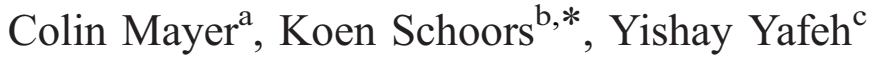 \\ ${ }^{a}$ Saïd Business School, University of Oxford and CEPR, UK \\ ${ }^{\mathrm{b}}$ Faculty of Economics and Business Administration, CERISE, Ghent University, Hoveniersberg 24, B-9000 \\ Ghent, Belgium \\ ${ }^{\mathrm{c}}$ Hebrew University of Jerusalem and CEPR, Jerusalem, Israel
}

Accepted 15 February 2004

Available online 6 May 2004

\begin{abstract}
We compare the investment activities and sources of finance of venture capital (VC) funds in Germany, Israel, Japan and the United Kingdom. VC investments differ across countries in terms of their stage, sector and geographical focus. Sources of VC funds also differ across countries; for example, banks are particularly important in Germany and Japan, corporations in Israel, and pension funds in the United Kingdom. Although the differences in investments are related to funding sources-for example, bank and pension fund-backed VCs invest in later stage activities than individual and corporate backed funds - a large proportion of variation within as well as between countries is unrelated to sources of finance. Moreover, differences in the relation between funding source and VC activity are unrelated to the country's financial systems. We conclude that neither financial systems nor sources of finance are the main explanations for the pronounced differences in $\mathrm{VC}$ activities.
\end{abstract}

(C) 2004 Elsevier B.V. All rights reserved.

JEL classification: $\mathrm{G} 20 ; \mathrm{O} 32$

Keywords: Venture capital financing; Investment stage

* Corresponding author. Tel.: +32 926489 74; fax: +32 92645999 .

E-mail address: koen.schoors@ugent.be (K. Schoors). 


\section{Introduction}

The role of the financial sector in promoting innovation has been extensively debated over a long period. The supply of risk capital and, in particular, the venture capital (VC) industry is viewed as critical to this, and financial systems and financial institutions are regarded as important determinants of the success of $\mathrm{VC}$ industries. This paper contributes to the literature on the economic role of the VC industry by examining the investments and sources of finance of $\mathrm{VC}$ funds in four countries, Germany, Israel, Japan and the United Kingdom, all of which have significant and/or rapidly growing $\mathrm{VC}$ industries.

The spread of countries is of special interest because it includes two bank-oriented systems (Germany and Japan), one (non-US) market-oriented system (the United Kingdom), and one major high-technology economy, Israel, which reportedly has a higher level of VC investment as a share of GDP than any OECD country. ${ }^{1}$ Within Europe, Germany and the United Kingdom are particularly important because together they account for over half of all VC investments on the Continent (BVK, 2000; the German Venture Capital Association). The paper therefore provides an international perspective on a VC literature that to date has been primarily focused on the United States. $^{2}$

Using hitherto unexplored qualitative data on about 500 venture capital funds, we examine their sources of finance, distinguishing between individuals, banks, insurance companies, pension funds, the government and other providers of finance.

We also examine the technological stage, sector and geographical distribution of investments by VCs in these four economies.

One observation that emerges from this analysis is that the term VC has quite different meanings around the world. For example, there are substantial variations across countries in the stage of investment in which the VC industry is engaged. Funds in Israel are focused on the type of early-stage investment with which VC is commonly associated; however, those in Japan are not, and German and UK funds on average operate somewhere between those in Israel and Japan.

There are also substantial variations across countries in sources of funds for the VC industry. Banks are a major source of VC finance in all countries, but they are particularly in evidence in Germany and Japan. Pension funds are prominent in the United Kingdom and corporations in Israel.

\footnotetext{
${ }^{1}$ OECD (2003).

${ }^{2}$ For example, in a collection of articles, Gompers and Lerner (1999) consider several financial aspects of VC investments and their impact on the performance of VC backed firms in the United States (e.g., at the time of the IPO). Lerner and Kortum (2000) study the influence of US VC funds on innovation, and Hellman and Puri (2000) evaluate the effect of US VC funds on the activities of their clients more generally. Gompers and Lerner (1996) as well as Kaplan and Stromberg (2003) examine the contractual environment in which VC funds operate, also within the United States. For more information on the empirical VC literature, see Manigart and Sapienza (2000) and Gompers and Lerner (2001). The theoretical VC literature is also, to a very large extent, motivated by observations about the US VC industry, e.g., with respect to the type of contracts used (e.g., Cornelli and Yosha, 2003; Hellman, 1998). Some information on VC activity outside the United States is provided in Bottazzi and Da Rin's (2002) survey on innovative firms in Europe and in Cumming's (2001) study of VC in Canada.
} 
Perhaps the most important contribution of the paper is an investigation of the relation between sources of finance of VC firms and the investment activities in which they are engaged. Our analysis offers preliminary answers to such questions as "are institutions like pension funds and life insurance companies with modest immediate liquidity requirements particularly involved in financing early-stage VC activities" and "do banks, with greater liquidity needs, invest in later stage $\mathrm{VC}$ activities"?

The data set on VC firms is well suited to an examination of these questions. It has unusually detailed information on both the sources of finance of $\mathrm{VC}$ funds and the investment activities in which they are engaged, albeit in qualitative rather than quantitative form, and it has an exceptionally wide coverage of this particular sector of the economy.

We find that bank-backed VC funds invest in later stage activities than private individual investors and corporations. Bank-backed funds also tend to invest domestically, while corporate-backed funds invest globally. However, funds with finance from other financial institutions with longer-term liabilities and less immediate liquidity needs, e.g., pension funds and insurance companies, are also focused on late-stage activities. We conclude that, while sources of finance appear to affect VC investment policies, liquidity is probably not the main driving factor.

The data allow the relations between financing and investment stage to be compared across countries, and therefore shed light on the emerging literature on international variations in financial systems. The differences we find do not correspond to conventional distinctions between "bank-based" and "market-based" financial systems. If anything, there is a greater similarity in the activities of VCs in Germany and the United Kingdom than in Germany and Japan. Moreover, there is a closer correspondence in the relation between sources of finance and VC activities in Germany and the United Kingdom than in Germany and Japan.

Overall, while there is a relation between sources of finance and VC activity, much of both the cross-country and within country variation is not attributable to funding. A large proportion of the within- and between-country variation is associated with variables that are unrelated to financing. Whatever has given rise to the pronounced differences in $\mathrm{VC}$ activities across and within countries, it is not primarily related to either differences in financial systems or sources of finance.

The paper proceeds as follows. Section 2 describes the data and provides descriptive statistics on VC firms in the four countries of this study. Section 3 presents and discusses the empirical results, and Section 4 concludes the paper.

\section{Data}

\subsection{Sources and sample coverage}

Our data are drawn from the individual countries' venture capital associations in Germany, Israel and the United Kingdom. For Germany and the United Kingdom, we use information from the European association of venture capitalists (http://www.evca.com) as well as from their respective national associations in the year 2000. For Israel, we use data 
provided by the Israeli association of venture capital (http://www.ivc-online.com) for 2000. For Japan, we rely on a survey conducted by Nikkei Kinyu (Financial Nikkei), 1999, on venture capital activities in Japan.

For Germany, Israel and the United Kingdom, we have data on all VC funds included in the associations, although some funds do not fully disclose data on their sources of funds and investment activities. Our database includes 187 German funds, 119 from Israel and 140 from the United Kingdom. ${ }^{3}$ Because both potential suppliers of finance and users of VC funds refer to the sources of information that we use in this study, there is an incentive for funds to provide accurate and timely information. For Japan, the survey includes information on $62 \mathrm{VC}$ funds, about half of the extant population of VC funds in Japan according to this survey. We have no reason to suspect any particular bias in this sample of respondents. ${ }^{4}$ In Germany, Japan, and the United Kingdom, information on individual VC funds is aggregated to the VC firm level (that is, multiple funds run by the same management appear as one observation). In Israel, some individual VC funds under the same management are recorded as separate observations.

For each VC fund, we collect information on fund size (Section 2.2), organizational form and types of investments (Section 2.3), sources of funds or ownership (Section 2.4), investment strategies by stage of investment (Section 2.5), sector (Section 2.6) and location of investment (Section 2.7). More details on the data set can be found in Appendix A, and comparisons with aggregate data on VC activities in these four countries are presented in Appendix B.

\subsection{Size of funds}

Measuring fund size in terms of assets under management, British venture capital funds are by far the largest, with mean capital of over 900 million US dollars, about eight times bigger than the average Japanese fund (US $\$ 115$ million) ${ }^{5}$ and 12 times bigger than the average Israeli fund (US\$73 million). Although no information on individual fund size is available for Germany, aggregate statistics suggest that the average German fund is about the same size as the average Israeli fund, with capital of about US\$77 million (BVK, 2000). Using medians rather than means suggests that in all countries, the majority of funds are much smaller. In the United Kingdom, the median VC has capital of about US\$140 million, compared with only US\$12 million in Japan and about US\$40 million in Israel. Interestingly, the median Israeli fund is bigger than the median Japanese fund, although both are much smaller than the median British VC.

\footnotetext{
${ }^{3}$ Membership of a particular country's VC association is open to funds operating in that country irrespective of where the fund is owned or controlled.

${ }^{4}$ A 2000 VC survey by the Japanese Ministry of Economy, Trade and Industry (METI, 2000) also lists about 60 respondents, which do not completely overlap with our list of funds (they refer to a much larger number of funds in existence in Japan). A 2001 survey conducted by Nikkei Venture Business Nenkan, is based on a larger sample of about $100 \mathrm{VC}$ funds and other providers of finance, but with only limited information on their activities. A survey conducted by the Asian Venture Capital Journal (2002) reports the existence of about 220 VC funds in Japan, although only about half of them are active (Lerner and Hardymon, 1999). Further information on the Japanese venture capital industry is available in Sako and Kelly (2002).

${ }^{5}$ The figure reported here is very close to the one cited by the Asian Venture Capital Journal (2002).
} 


\subsection{Corporate form and types of investment}

VC firms have different legal structures in the four countries of our sample. In the Japanese sample, all VC funds are joint stock companies, often affiliates of banks and securities companies. ${ }^{6}$ In Germany about a quarter of the funds are listed companies (AGs), and in the United Kingdom, limited partnership is the most common form of VC organization (only about $5 \%$ of the funds are public companies).

Data on types of investment made by funds are available for Germany and Israel. In both countries, equity is the dominant form of investment, unlike the United States, where convertible securities have been documented as the most common form of VC finance. Lerner and Hardymon (1999) report, that equity finance is common among Japanese VC funds as well. Loans are provided by about one-sixth of funds in Germany, and in Israel convertible debt (but not straight debt) is provided by about half of the funds. ${ }^{7}$

\subsection{Sources of finance}

As noted, all venture capital funds in our Japanese sample are joint stock companies, and their owners are also their investors and providers of funds. In other countries, funds report whether they received finance from a certain category of investors. The data reported below are a snapshot of the stock of sources of finance used by VC funds, rather than a flow of money in a given period, or financing patterns over time. With the exception of Japan, our data sources do not provide the precise amounts of money received from each source, and we therefore define a number of qualitative and not mutually exclusive dummy variables that equal one if the fund reports having used a given source of finance. These dummies signify whether there is bank finance, finance from insurance companies, pension funds, other financial institutions, corporate investors, individual investors, or the government and regional authorities.

Table 1, which displays the sources of external finance for the VC industry in the four countries, documents some important differences. In Germany, banks are by far the most important source of finance for the VC industry, and pension funds are conspicuously absent. ${ }^{8}$ By contrast, in the UK pension funds, other institutional investors,

\footnotetext{
${ }^{6}$ Sako and Kelly (2002) note that it was only in 1998 that the Japanese government enacted the Limited Partnership for Venture Capital Investment (Toshi jigyo yugensekinin kumiai ho) that defined the legal basis for the limited liability of nongeneral partners.

${ }^{7}$ Cumming (2001) provides evidence that VC contracts in Canada also involve a variety of financial contracts, in contrast with the convertible securities typically used in the United States. He also makes references to studies documenting similar contracts between VC and client firms in various countries. Bascha and Walz (2001) study the organization of the venture capital industry in Germany, and document the use of various types of financial contracts, which, in their view, depend on the severity of agency problems. Gilson and Schizer (2002) argue that tax considerations account for the differences between the United States and other countries in this respect.

${ }^{8}$ In the German data, up to 1999 , pension fund contributions to VC funding have been small (BVK, 2000) and are included in the category "other financial institutions." BVK (2000) suggests that, as a result of ongoing reforms in the German pension system, pension funds have become a much more important source of funds for the VC industry. Differences between Germany and the United Kingdom in this respect may therefore diminish over the next few years.
} 
Table 1

Sources of external funds for the VC industry

Panel A: Fraction of funds using particular sources

\begin{tabular}{|c|c|c|c|c|c|c|c|c|}
\hline & Funds & Banks & $\begin{array}{l}\text { Insurance } \\
\text { companies }\end{array}$ & $\begin{array}{l}\text { Pension } \\
\text { funds }\end{array}$ & $\begin{array}{l}\text { Corporate } \\
\text { investors }\end{array}$ & $\begin{array}{l}\text { Individual } \\
\text { investors }\end{array}$ & Government & $\begin{array}{l}\text { Other } \\
\text { institutions }\end{array}$ \\
\hline Germany & 187 & $0.59 * *$ & $0.22 * *$ & $0 * *$ & $0.16^{* *}$ & $0.36^{*}$ & $0.09 * *$ & $0.21 * *$ \\
\hline Israel & 119 & 0.51 & $0.11 * *$ & $0.02 * *$ & $0.60 * *$ & 0.36 & $0.01 * *$ & 0.54 \\
\hline Japan & 62 & 0.56 & 0.43 & $0 * *$ & 0.27 & $0.21 * *$ & $0.03 * *$ & $0.80 * *$ \\
\hline United Kingdom & 140 & 0.44 & 0.36 & 0.49 & 0.26 & 0.45 & 0.24 & 0.55 \\
\hline
\end{tabular}

Panel B: Percentage of funds using particular number of sources

\begin{tabular}{lllll}
\hline & One $(\%)$ & Two $(\%)$ & Three $(\%)$ & Four or more $(\%)$ \\
\hline Germany & 61 & 22 & 9 & 8 \\
Israel & 38 & 27 & 21 & 15 \\
Japan & 21 & 39 & 29 & 11 \\
United Kingdom & 35 & 16 & 10 & 39 \\
\hline
\end{tabular}

This table reports sources of funds of VC firms in Germany, Israel, Japan and the United Kingdom based on binary and not mutually exclusive responses to a question of whether or not a particular fund uses a certain source. Panel A displays the proportion of funds that report using a given source. Panel B displays the percentage of funds using one, two, three, or four or more sources.

* Mean values which are statistically different from those of the United Kingdom at the $10 \%$ level.

** Mean values which are statistically different from those of the United Kingdom at the 5\% level. 
and individual investors provide funds to as many companies as banks. Contrary to popular views, government (typically local authority) funding plays a more important role in the United Kingdom than it does in Germany, and is negligible in the other countries.

Sources of funds for the Israeli VC industry are widespread, with industrial corporations (typically from the United States) being the single most popular source of funds. In Japan, nonbank financial institutions (e.g., securities firms, credit card or leasing companies and mortgage institutions) are the single most important category of finance among Japanese funds, followed by banks and insurance companies. ${ }^{9}$ It is quite common in Japan for the owners/providers of finance for Japanese VC funds to be all affiliated with the same bank-centered corporate group, or to be otherwise related to each other. In over half of the Japanese funds in our sample, at least three of the five largest shareholder providers of finance are related to each other or affiliated with the same group.

$\mathrm{VC}$ funds in Germany tend on average to use fewer sources of funds than do VCs in other countries (Table 1, Panel B). By contrast, funds in Israel, Japan and the United Kingdom tend to use many sources of finance; in particular, about a third of the UK funds report using at least four different sources. ${ }^{10}$ Relying exclusively on bank finance is also very common in Germany: over $60 \%$ of the VC funds that raise money from banks use this source exclusively; the corresponding figure for the United Kingdom is about one-third, and for Israel about one-fifth. Surprisingly, despite the typical characterization of the Japanese economy as bank dominated (like Germany), only one-seventh of the Japanese VC funds in our sample rely exclusively on bank finance.

\subsection{Type of investment activity: investment stage}

Table 2 provides statistics on the type of investment activity funded by VCs in the four countries, characterizing investments by the technological stage at which they are made, sector and geographical focus. Panel A displays the percentage of VC funds investing in different stages. ${ }^{11}$ The VC industry in Israel provides finance primarily to companies in early stages of development (nearly all funds report positive investments in firms in their early stages). VC funds in Germany and the United Kingdom provide funding to companies in all stages with a slight bias towards later stages of development (this

\footnotetext{
${ }^{9}$ Some, but not all, of these institutions are partly bank owned, sometimes indirectly. However, we do not track the ultimate ownership of any of the institutions providing finance to $\mathrm{VC}$ companies.

${ }^{10}$ A Kolmogorov-Smirnov test for equality of distributions indicates that the distributions of funds according to the number of sources used differ in Germany, Japan, and Israel from that of the United Kingdom.

${ }^{11}$ Funds report their focus on one or more categories of investments (seed, start-up, middle, expansion and growth, and later stages including refinancing and management buy-ins and buyouts) without specifying the precise amounts invested in each activity. We categorize stages as "early" for seed and start-up, "middle" for middle, expansion and growth investments, and "late" for later stage investments, including refinancing and management buy-ins and buyouts. In the Japanese data, the stage definitions are somewhat different, but the three categories in the survey correspond to early, middle and later stages. We discuss the possible impact of differences in the stage definitions between Japan and the other countries in the sample below.
} 
Table 2

Characteristics of $\mathrm{VC}$ investments

\begin{tabular}{|c|c|c|c|c|c|c|}
\hline \multicolumn{7}{|c|}{ Panel A: VC Investments by stage } \\
\hline & Funds & Early (1) & Middle (2) & Late (3) & & \\
\hline Germany & 187 & $0.68 * *$ & $0.89 *$ & 0.74 & & \\
\hline Israel & 98 & $0.93 * *$ & $0.49 * *$ & $0.28 * *$ & & \\
\hline Japan & 57 & $0.15 * *$ & $0.19 * *$ & $0.65 * *$ & & \\
\hline United Kingdom & 140 & 0.48 & 0.84 & 0.80 & & \\
\hline \multicolumn{7}{|c|}{ Panel B: VC investments by industry } \\
\hline & Funds & $\begin{array}{l}\text { Life } \\
\text { sciences }\end{array}$ & $\begin{array}{l}\text { IT and } \\
\text { software }\end{array}$ & $\begin{array}{l}\text { Electronics and } \\
\text { semiconductors }\end{array}$ & $\begin{array}{l}\text { Manufacturing } \\
\text { and chemicals }\end{array}$ & $\begin{array}{l}\text { Other } \\
\text { industries }\end{array}$ \\
\hline Germany & 183 & 0.84 & $0.81 * *$ & 0.73 & 0.68 & 0.73 \\
\hline Israel & 95 & $0.57 * *$ & 0.89 & $0.49 * *$ & $0.24 * *$ & $0.09 * *$ \\
\hline Japan & 56 & $0.55 * *$ & $0.86 * *$ & $0.11 * *$ & $0.14 * *$ & $0.34 * *$ \\
\hline United Kingdom & 140 & 0.81 & 0.96 & 0.79 & 0.78 & 0.75 \\
\hline
\end{tabular}

Panel C: Percentage of funds investing in certain number of industries

\begin{tabular}{lclll}
\hline & One $(\%)$ & Two $(\%)$ & Three $(\%)$ & Four or five $(\%)$ \\
\hline Germany & 9 & 16 & 15 & 60 \\
Israel & 39 & 23 & 17 & 21 \\
Japan & 3 & 12 & 42 & 42 \\
United Kingdom & 11 & 7 & 7 & 75
\end{tabular}

Panel D: VC investments by region

\begin{tabular}{lcclll}
\hline \multicolumn{5}{l}{ Percentage of Funds Investing in Different Locations } \\
\hline \multicolumn{7}{l}{ Funds } & $\begin{array}{l}\text { Region } \\
\text { within } \\
\text { country (1) }\end{array}$ & $\begin{array}{l}\text { Country } \\
\text { only (2) }\end{array}$ & $\begin{array}{l}\text { Country and } \\
\text { continent (3) }\end{array}$ & Worldwide (4) \\
\hline Germany & 187 & $34 \%$ & $32 \%$ & $18 \%$ & $17 \%$ \\
Israel & 97 & $1 \%$ & $67 \%$ & $25 \%$ & $7 \%$ \\
Japan & 55 & $13 \%$ & $44 \%$ & $38 \%$ & $5 \%$ \\
United Kingdom & 139 & $16 \%$ & $24 \%$ & $35 \%$ & $24 \%$ \\
\hline
\end{tabular}

This table reports the characteristics of VC investments based on discrete and not mutually exclusive responses by funds. Panel A refers to investment stage and reports the proportion of funds investing in different investment stages: "early" refers to seed and start-up, "middle" to expansion and growth, and "late" to later stages. Panel B refers to the sectors of investment using five groups of industries: life sciences, IT and software, electrical and semiconductors, manufacturing and chemicals, and other industries. Panel $\mathrm{C}$ records the percentage of funds investing in one, two, three, or four or more industries. Panel D records the regional, national or international nature of investments by funds. It reports the percentage of funds investing in a region within a country, in several regions within a country, within a single continent, or in two or more continents (the definition for Japan is slightly different, see text).

* Mean values which are statistically different from those of the United Kingdom at the $10 \%$ level.

** Mean values which are statistically different from those of the United Kingdom at the 5\% level.

bias is more pronounced for the United Kingdom than for Germany). In Japan, VC funds are predominantly directed at companies in (middle and) later stages of development with very little support for seed and start-up companies. 


\subsection{Type of investment activity: sector}

VC funds record the industries in which they invest, without specifying precise amounts. We classify these investments into one or more of the following five categories: (1) life sciences, biotechnology and environmental technology; (2) software, communication and information technology; (3) electronics and semiconductors; (4) manufacturing (including chemicals); (5) services and other sectors. Panel B of Table 2 reports substantial differences in the industry distribution of $\mathrm{VC}$ investments in the three countries. VCs in Israel and Japan invest predominantly in the IT and software industry, whereas the distribution of investments across industries in Germany and the United Kingdom is more even, and surprisingly similar to each other. Another surprising result is that, in Japan, the electronics and semiconductor sectors seems to be a less favoured target for $\mathrm{VC}$ investments than it is in other countries, perhaps because $\mathrm{R} \& \mathrm{D}$ in this sector is carried out within large companies. Manufacturing and chemicals are relatively more popular in Germany and the United Kingdom. Panel $\mathrm{C}$ of Table 2 reports the number of industries in which $\mathrm{VC}$ funds, on average, invest in the four countries. Funds are heavily diversified across sectors (four or five) in the United Kingdom and Germany, and somewhat less so in Japan. In Israel, many more funds are concentrated in only one sector. ${ }^{12}$

\subsection{Type of investment activity: location}

Finally, we gather information on the geographical concentration of fund investments in specific regions or countries (Panel D of Table 2). We assign the number 1 to a fund if it invests within a single region within a country; 2 , if it invests anywhere in its domestic country; 3 , if it operates within a single continent; 4 , if it operates worldwide (i.e., in two or more continents). ${ }^{13} \mathrm{UK}$ VCs are the most international with $60 \%$ of funds having some investments outside the United Kingdom. By contrast, two-thirds of German funds invest only in Germany (or in a region within Germany). ${ }^{14}$

Taken together, Tables 1 and 2 suggest that if anything there is a greater similarity in the stage, sector composition and significance of institutional funding of VCs in Germany and the United Kingdom than in Germany and Japan. The tables also document more early-stage investment in Israel than in the much larger stock market economy of the United Kingdom.

\footnotetext{
${ }^{12}$ Indeed, a Kolmogorov- Smirnov test for equality of distributions indicates that the distributions of funds according to the number of industries they invest in are not significantly different between Germany and the United Kingdom, whereas the distributions for Japan, and Israel do differ (are more concentrated) from that of the United Kingdom.

${ }^{13}$ Because Japanese companies report the fraction of their investments invested abroad (with no geographical breakdown), we construct the variable for Japan in a slightly different way. We assign the number 1 to it if the fund is regional; 2, if it invests in Japan only; 3, if it invests up to $50 \%$ of its funds abroad; and 4, if over $50 \%$ of the fund's investment are abroad.

14 A Kolmogorov-Smirnov test for equality of distributions indicates that the distributions of funds according to the location of their investments differ in Germany, Japan, and Israel from that of the United Kingdom.
} 
These observations suggest that, at least in this four-country sample, there is no simple association of VC activity with the financial systems within which they operate, in contrast with some of the conventional wisdom on financial systems. Allen (1993) and Allen and Gale (1999) argue that stock markets allow investors to hold diverse views about investments, whereas banks can exploit economies in acquiring information about firms where there is a high degree of consensus. Securities markets are therefore particularly relevant where investors have diverse views about, e.g., new technologies. The similarity of VC investments in Germany and the United Kingdom is inconsistent with this view.

Black and Gilson (1998) view stock markets as particularly suited to the high risks of early-stage investments, and bank-oriented systems to the more traditional, late-stage investments. The early-stage investment by Israeli VC funds in contrast to that in the United Kingdom casts doubt on this view as well.

The next section will suggest that variations across countries in relations between sources of finance and VC activities are also inconsistent with conventional dichotomies between bank-based and market-based financial systems.

\section{The determinants of $\mathrm{VC}$ investments}

\subsection{Partial correlation coefficients}

Table 3 reports partial correlation coefficients between sources of finance, country dummies, stage and geographical focus of investment. As previously noted there is a preponderance of bank but not other sources of finance in Germany, of corporate in Israel, of bank, insurance and other financial institutions in Japan and of insurance, government, individual and in particular pension fund finance in the United Kingdom. Some combinations of sources of finance are common; in particular, pension fund finance is associated with insurance company and government finance. Other combinations are less common, e.g., corporate or individual with bank finance.

Israeli funds are early-stage investors and Japanese and UK funds tend to be later stage investors. There is a weak negative association between bank, insurance and pension-backed funds and early-stage investment, and a positive correlation with later stages. Conversely, there is a positive correlation between corporate and individual investor-backed funds and early-stage investment and a negative correlation with later stages. Bank and government finances are associated with a local and national focus to VC investments. Pension fund, insurance, corporate and individual finances are associated with a more international focus.

\subsection{Sources of finance and VC investments: regression results}

We examine the relation between stage of investment and sources of finance using two types of regression. The first is a probit regression where the dependent variable is a dummy which takes the value 1 for investment in early or late (as against middle) stage. The equations are estimated as seemingly unrelated (SUR) probit regressions. The second 
Table 3

Partial correlation coefficients

\begin{tabular}{|c|c|c|c|c|c|c|c|c|c|c|}
\hline & Early & Late & $\begin{array}{l}\text { Geographical } \\
\text { focus }\end{array}$ & Bank & Insurance & Pension & Corporate & Individual & Government & Other \\
\hline Bank & -0.05 & 0.09 & -0.12 & & & & & & & \\
\hline Insurance & -0.16 & 0.08 & 0.14 & 0.16 & & & & & & \\
\hline Pension & -0.15 & 0.15 & 0.16 & 0.02 & 0.36 & & & & & \\
\hline Corporate & 0.13 & -0.20 & 0.21 & -0.01 & 0.17 & 0.14 & & & & \\
\hline Individual & 0.11 & -0.07 & 0.10 & -0.15 & 0.13 & 0.19 & 0.03 & & & \\
\hline Government & -0.03 & 0.07 & -0.08 & 0.11 & 0.17 & 0.31 & 0.10 & 0.10 & & \\
\hline Other & -0.09 & -0.02 & 0.10 & 0.01 & 0.28 & 0.31 & 0.20 & 0.06 & 0.06 & \\
\hline Germany & 0.07 & 0.17 & -0.14 & 0.09 & -0.08 & -0.33 & -0.22 & -0.03 & -0.04 & -0.38 \\
\hline Israel & 0.35 & -0.41 & -0.03 & -0.01 & -0.16 & -0.18 & 0.32 & 0.01 & -0.16 & 0.11 \\
\hline Japan & -0.34 & 0.01 & -0.01 & 0.02 & 0.14 & -0.15 & 0.00 & -0.11 & -0.11 & 0.25 \\
\hline United Kingdom & -0.19 & 0.21 & 0.19 & -0.11 & 0.13 & 0.62 & -0.04 & 0.10 & 0.26 & 0.13 \\
\hline
\end{tabular}

This table reports partial correlation coefficients between sources of funds (categorized as a nonexclusive dummy of whether a fund reported using banks, insurance companies, pension funds, corporations, individuals, government or other financial institutions), the country of origin of the $\mathrm{VC}$ fund, the stage of investment (categorized as a nonexclusive dummy of whether a fund reported investing in early or late stage activities) and geographical focus (on a scale of 1-4 depending on whether a fund invests in a region within a country, a country only, a continent or worldwide). 
set of regressions is an ordered probit, where the dependent variable is an ordered measure of the stage of investment. This measure is constructed as follows: ${ }^{15}$

\begin{tabular}{llll}
\hline Early & Middle & Late & Order \\
\hline 1 & 0 & 0 & 1 \\
1 & 1 & 0 & 2 \\
1 & 1 & 1 & 3 \\
1 & 0 & 1 & 3 \\
0 & 1 & 0 & 3 \\
0 & 1 & 1 & 4 \\
0 & 0 & 1 & 5 \\
\hline
\end{tabular}

We also estimate the determinants of the geographical focus of investment using ordered probit regressions, where the dependent variable takes values between 1 and 4, depending on whether the VC is focused on local, national, continent wide or global investments (see Section 2.7).

Table 4 presents estimates of the relations between stages of investment and sources of finance. The SUR probit regressions on the pooled samples in columns 1 and 2 of Panel A reveal that bank, insurance company and pension fund backed VC funds are all associated with more late and less early-stage investments. In contrast, corporate, individual and government-backed funds are associated with more early-stage and less late-stage investments. The results for corporate and individual financing are particularly significant, but there is also evidence of significant bank and pension fund effects. There is no consistent relation with "other" financial institution sources.

The ordered probit stage regressions in Panel B of Table 4 confirm the results. There is a positive relation of stage (i.e., later stage) with bank, insurance companies and pension fund-backed funds and a negative relation of stage with corporate, individual, and government-backed funds. The relation with bank, pension and individual funding sources are significant. There is little relation with "other" financial institution source.

The country dummy variables show that, over and above the funding source effects, Israel is heavily focused on early-stage investments (its dummy variables are highly significant in all the regressions) relative to the United Kingdom. Japan is focused on latestage investments, and Germany is slightly earlier stage focused than the United Kingdom. In Panel A, the coefficient on the Japan dummy is negative in both the early and late-stage regressions reflecting the fact that Japanese funds tend to invest in one stage (middle or late), whereas UK funds invest in several stages. The size of the country dummies is large. According to column 1 in Panel B of Table 4, the unexplained difference between the United Kingdom and Israel stage of investment [the coefficient on the Israel dummy (1.16)] is comparable in magnitude to a VC fund switching its sources from corporations,

\footnotetext{
15 Alternative ranking schemes are also possible. For example, it is possible to divide all funds into three instead of five categories: funds investing in early stages alone (category 1); funds investing in late stages alone (category 3); and all the remaining funds whose investment strategies are less extreme (category 2). This ranking scheme yields empirical results that are very similar to those of the five stage ranking.
} 
Table 4

Estimates of the determinants of the stage of investment

Panel A: Seemingly unrelated probit and simple probit estimates

\begin{tabular}{|c|c|c|c|c|c|c|}
\hline & $\begin{array}{l}\text { Early stage } \\
\text { pooled } \\
\text { sample }\end{array}$ & $\begin{array}{l}\text { Late stage } \\
\text { pooled } \\
\text { sample }\end{array}$ & $\begin{array}{l}\text { Late stage, } \\
\text { Germany }\end{array}$ & $\begin{array}{l}\text { Late stage, } \\
\text { Israel }\end{array}$ & $\begin{array}{l}\text { Late stage, } \\
\text { Japan }\end{array}$ & $\begin{array}{l}\text { Late stage, } \\
\text { United } \\
\text { Kingdom }\end{array}$ \\
\hline Constant & $0.02(0.17)$ & $0.88 * *(0.19)$ & $0.77 * *(0.24)$ & $-0.52(0.33)$ & $1.86 * *(0.70)$ & $0.65 * *(0.22)$ \\
\hline Bank & $-0.05(0.13)$ & $0.25 *(0.13)$ & $0.17(0.24)$ & $-0.03(0.31)$ & $-0.17(0.39)$ & $0.75 * *(0.31)$ \\
\hline Insurance & $-0.18(0.16)$ & $0.06(0.16)$ & $0.29(0.29)$ & $0.18(0.45)$ & $0.06(0.39)$ & $-0.17(0.39)$ \\
\hline Pension & $-0.45 *(0.25)$ & $0.31(0.27)$ & N/A & N/A & N/A & $0.44(0.38)$ \\
\hline Other & $0.06(0.15)$ & $0.08(0.15)$ & $0.57 *(0.29)$ & $0.06(0.30)$ & $-1.47 * *(0.67)$ & $-0.13(0.30)$ \\
\hline Corporate & $0.26(0.16)$ & $-0.31 * *(0.15)$ & $-0.86 * *(0.27)$ & $0.04(0.30)$ & $0.20(0.43)$ & $-0.72 *(0.37)$ \\
\hline Individual & $0.31 * *(0.14)$ & $-0.29 * *(0.13)$ & $-0.41 *(0.23)$ & $-0.23(0.33)$ & $-0.80 *(0.47)$ & $0.14(0.38)$ \\
\hline Government & $0.09(0.20)$ & $-0.13(0.21)$ & $-0.53(0.33)$ & N/A & N/A & $0.30(0.35)$ \\
\hline Germany & $0.33 *(0.18)$ & $-0.24(0.20)$ & & & & \\
\hline Israel & $1.32 * *(0.27)$ & $-1.35 * *(0.23)$ & & & & \\
\hline Japan & $-1.17 *(0.27)$ & $-0.57 * *(0.26)$ & & & & \\
\hline$N$ & 482 & 482 & 187 & 95 & 56 & 140 \\
\hline Log likelihood & -475.2 & & -95.6 & -57.2 & -31.6 & -60.3 \\
\hline
\end{tabular}

Panel B: Ordered probit regressions

\begin{tabular}{|c|c|c|c|c|c|}
\hline & Full sample & Germany & Israel & Japan & United Kingdom \\
\hline Bank & $0.19 *(0.10)$ & $-0.08(0.18)$ & $0.41(0.26)$ & $-0.11(0.36)$ & $0.49 * *(0.20)$ \\
\hline Insurance & $0.17(0.13)$ & $0.47 * *(0.21)$ & $0.13(0.38)$ & $0.30(0.36)$ & $-0.08(0.25)$ \\
\hline Pension & $0.39 *(0.20)$ & N/A & $-0.48(0.85)$ & N/A & $0.62 * *(0.26)$ \\
\hline Other & $-0.01(0.12)$ & $0.20(0.20)$ & $-0.00(0.26)$ & $-1.49 * *(0.63)$ & $-0.09(0.22)$ \\
\hline Corporate & $-0.18(0.12)$ & $-0.64 * *(0.22)$ & $0.10(0.25)$ & $0.13(0.41)$ & $-0.40(0.26)$ \\
\hline Individual & $-0.21 * *(0.10)$ & $-0.42 * *(0.18)$ & $0.02(0.27)$ & $-0.40(0.43)$ & $-0.22(0.20)$ \\
\hline Government & $-0.16(0.16)$ & $-0.63 * *(0.27)$ & N/A & N/A & $0.23(0.23)$ \\
\hline Germany & $-0.20(0.15)$ & & & & \\
\hline Israel & $-1.16^{* *}(0.19)$ & & & & \\
\hline
\end{tabular}


Panel C: Ordered probit regressions controlling for the size of funds (not available for Germany), excluding VC firms only operating at a regional level, and controlling for industry

\begin{tabular}{lccc}
\hline & $\begin{array}{l}\text { Including size } \\
\text { of funds }(1)\end{array}$ & $\begin{array}{l}\text { Excluding } \\
\text { regional } \\
\text { funds }(2)\end{array}$ & $\begin{array}{l}\text { Including control } \\
\text { for high- tech } \\
\text { industries (3) }\end{array}$ \\
\hline Bank & $0.30^{* *}(0.14)$ & $0.25^{* *}(0.11)$ & $0.18^{*}(0.10)$ \\
Insurance & $0.13(0.18)$ & $0.15(0.13)$ & $0.13(0.13)$ \\
Pension & $0.29(0.22)$ & $0.29(0.22)$ & $0.30(0.20)$ \\
Other & $-0.13(0.15)$ & $-0.03(0.13)$ & $0.00(0.12)$ \\
Corporate & $-0.13(0.15)$ & $-0.24^{*}(0.13)$ & $-0.13(0.12)$ \\
Individual & $-0.28^{* *}(0.14)$ & $-0.23^{* *}(0.12)$ & $-0.14(0.11)$ \\
Government & $0.05(0.22)$ & $0.09(0.23)$ & $-0.19(0.17)$ \\
Fund size & $0.07^{*}(0.04)$ & $\mathrm{N} / \mathrm{A}$ & $\mathrm{N} / \mathrm{A}$ \\
$\quad$ billion US $\$)$ & $\mathrm{N} / \mathrm{A}$ & $-0.11(0.17)$ & $-0.19(0.15)$ \\
Germany & $-1.00^{* *}(0.20)$ & $-1.14^{* *}(0.20)$ & $-1.01 * *(0.19)$ \\
Israel & $1.05^{* *}(0.24)$ & $0.96^{* *}(0.23)$ & $1.28^{* *}(0.22)$ \\
Japan & 271 & 389 & 482 \\
$N$ & 0.15 & 0.12 & 0.13 \\
Pseudo $R^{2}$ & & & \\
\hline
\end{tabular}

This table reports the results of regressions of stages of investment on sources of funds. Columns 1 and 2 of Panel A display the full- sample results of seemingly unrelated probit estimates where the dependent variables are dummy variables signifying Early and Late stages. The other columns of Panel A display individual country probit regressions. The left column of Panel B displays full- sample ordered probit results where the dependent variable is an ordered measure of the investment stage (see text). The other columns report the results of a similar regression for individual countries. The regressions in Panel C are similar to those in Panel B, with controls for size of funds, excluding regional funds, and controlling for investment in high tech industries (the regression includes a dummy variable which equals one if the fund invests exclusively in life sciences, IT and software, and electronics and semiconductors).

* Statistical significance at the $10 \%$ level.

** Statistical significance at the $5 \%$ level. 
individuals and government to banks, insurance companies and pension funds (a total coefficient of 1.30). A large proportion of the international variation in investment stage is therefore not explained by financial sources.

The relations between sources of funds and investment strategies in Table 4 are closely related to arguments in the literature on the financial aspects of VC. Gompers and Lerner (1998) emphasize the significance of pension funds, which accounted for more than 40\% of VC funding in the United States between 1993 and 1997. They attribute the growth of VC activity in the 1980s to the relaxation of the "prudent man" rule governing pension fund investments. Our findings cast doubt on the notion that early-stage investment by VCs is dependent on the availability of pension fund finance.

Hellman et al. (2003) examine the relation between banks' provision of VC and loans.Consistent with our results, they report that banks are reluctant to originate and are more prone to syndicate deals. They also find a reluctance of banks to participate in early stage deals more generally as reflected in lower involvement by them in initial rounds of financing.

Turning to corporate-backed venture capital firms, Hellman (2002) argues that the strategic objectives of corporate investors make them a preferred source of finance for entrepreneurs with activities that are complementary to those of the corporations. Within a contracting model framework, he also proposes an explanation for the stylised fact that (US) corporations play a modest role in financing start-ups. Our results suggest that US corporations do invest in start-ups in Israel, perhaps because of what Gompers and Lerner (2000) call "strategic overlaps" with their activities. Gompers and Lerner (2000) also suggest that the premium paid is lower and the stability of corporate programs greater where there is a strategic focus to their investments. Consistent with this, Panel $\mathrm{C}$ of Table 2 reported an exceptionally high degree of sector focus of Israeli VC funds.

The results in Table 4 are also related to studies of the investment preferences of financial institutions. Winton (2003), for example, argues that banks, whose liquidity needs are substantial, should prefer (debt) holdings in low risk firms. Pension funds and life insurance firms with less immediate liquidity requirements should, according to this view, prefer (equity) holdings in higher risk firms. Whereas the prediction about bank investments is supported by our findings, the one about pension funds and insurance companies is not.

Panel $\mathrm{C}$ of Table 4 presents three robustness tests. First, we control for the size of funds in the ordered probit regression (column 1 of Panel C); size of funds is not available in Germany, but in other countries, the coefficient on the size of funds is positive and significant. The coefficients on bank, insurance companies and pension funds remain positive throughout, and those on corporate and individuals remain negative. The coefficient on government finance is insignificantly positive controlling for the size of funds, perhaps because of the exclusion of Germany from the regression, a country in which the relation between government finance and stage is particularly negative (see Table 4, Panel B).

Second, an implicit assumption behind our analysis is that VC funds face a common demand by entrepreneurs, so that differences in their investment strategies 
reflect only the preferences of their providers of finance. This may not be the case for VCs operating at a regional rather than a national or international level because their investment opportunities may have been restricted by factors other than sources of finance. To test this, we rerun the regressions excluding the 93 regional funds. Column 2 of Panel $\mathrm{C}$ shows that the results remain almost unchanged.

Third, there may be a variation in VC firms operating in different sectors. However, little is changed when a dummy variable for VCs investing exclusively in relatively hightech sectors (life sciences, software, and electronics) is included in the regression (column 3 of Panel C).

Finally, management buy-in and buyout activity is extremely rare in Japan, suggesting that some of the funds classified as engaged in financing later stage activities in the Japanese survey could perhaps be viewed as supporting middle stage companies according to the other data sources. Lerner and Hardymon's (1999) description of VC activity in Japan is also consistent with this view. To address this possibility, we estimate a specification where all Japanese funds with later stage investments are converted into middle stage, and find no significant changes in the coefficients on the sources of finance, although this conversion changes the signs of the Japan country dummy from positive to negative.

The last four columns of Panels A and B of Table 4 compare the regression results for the four countries of the study individually. ${ }^{16}$ The positive influence of bank finance and pension funds on stage is particularly associated with the United Kingdom and not much in evidence elsewhere. The negative influence of corporate, individual and government finance on stage is particularly in evidence in Germany. Insurance funds are associated with later stage investment in Germany and other financial institutions, which are prominent in Japan, are associated with earlier stage finance. There is little influence of any finance source on stage of investment in Israel, reflecting the strong focus of Israeli funds on early-stage investments. The association of later stage investment with institutional as against corporate and individual funding is therefore a feature of Germany and the United Kingdom but not Israel and Japan.

This result is at variance with Allen and Gale's (2000) prediction that there are systematic variations in the functions performed by similar institutions in different countries. Allen and Gale contrast economies in which risks can be diversified at a particular point in time using financial instruments with those in which they are smoothed over time by banks. Where banks perform an intertemporal smoothing function, e.g., in Germany and Japan, they absorb the risks that individuals and institutions hedge with financial instruments in, e.g., the United Kingdom and the United States. German and Japanese banks would therefore be expected to engage in more risk taking than banks in the United Kingdom and the United States. While there is some evidence that UK banks invest in later stages than those in other countries, early-stage investment in Germany is more closely associated with corporate and individual investors than with banks.

\footnotetext{
16 To save space, country-specific probit regressions where the dependent variable is early stage investment are not shown.
} 
Table 5

Ordered probit estimates of the determinants of geographical focus

\begin{tabular}{lccccc}
\hline & Full sample & Germany & Israel & Japan & United Kingdom \\
\hline Bank & $-0.21^{* *}(0.10)$ & $-0.35^{*}(0.19)$ & $-0.26(0.28)$ & $0.16(0.32)$ & $-0.13(0.20)$ \\
Insurance & $0.28^{* *}(0.12)$ & $0.66^{* *}(0.21)$ & $-0.73(0.46)$ & $-0.62 *(0.32)$ & $0.25(0.25)$ \\
Pension & $-0.02(0.20)$ & N/A & $-1.39(1.06)$ & N/A & $0.02(0.26)$ \\
Other & $0.02(0.11)$ & $-0.10(0.21)$ & $0.19(0.28)$ & $0.25(0.42)$ & $0.30(0.22)$ \\
Corporate & $0.56^{* *}(0.12)$ & $0.88^{* *}(0.23)$ & $0.54 *(0.29)$ & $0.57(0.38)$ & $0.36(0.25)$ \\
Individual & $0.19^{*}(0.10)$ & $0.43^{* *}(0.18)$ & $0.20(0.30)$ & $0.47(0.39)$ & $-0.41^{*}(0.20)$ \\
Government & $-0.70^{* *}(0.17)$ & $-0.91^{* *}(0.31)$ & N/A & N/A & $-0.31(0.24)$ \\
Germany & $-0.52^{* *}(0.15)$ & N/A & N/A & N/A & N/A \\
Israel & $-0.52^{* *}(0.18)$ & N/A & N/A & N/A & N/A \\
Japan & $-0.41^{*}(0.20)$ & N/A & N/A & N/A & N/A \\
$N$ & 478 & 187 & 97 & 55 & 139 \\
Pseudo $R^{2}$ & 0.06 & 0.11 & 0.05 & 0.05 & 0.03 \\
\hline
\end{tabular}

The table reports the results of ordered probit regressions of geographical focus (which takes values between 1 and 4 , where 1 corresponds to investment within a region within a country, 2 to investment in one country, 3 to investment in a continent, and 4 to worldwide investments) on sources of funds. The first column relates to the full sample and the remaining four columns to individual country regressions.

* Statistical significance at the $10 \%$ level.

** Statistical significance at the $5 \%$ level.

\subsection{Geographical focus}

Table 5 reports ordered probit estimates of the relation between geographical focus of VC funds and their sources of finance. Bank-backed VC funds tend to invest more locally, whereas funds backed by insurance companies, corporations and individual investors tend to invest more abroad. Government funding is closely associated with local and national investment. These relations are particularly significant in the German sample. In Israel, sources of finance have little impact on geographical focus, except that corporate backing, the main source of VC financing in Israel, tends to be associated with more international investment. Unlike the case of the stage of investment, the country-specific intercepts (dummies) for Germany, Israel and Japan are not statistically different from one another.

To summarize, the regressions report a significant relation between sources of finance and both stage and geographical focus of investments. Financial institution (bank, pension fund and insurance company) backed funds are focused on late-stage investments and individual and corporation backed funds are focused on early-stage investments. These relations are particularly in evidence in Germany and the United Kingdom. Bank and government backed funds invest locally and insurance company, corporation and individual investor backed funds invest globally. This relation is particularly pronounced in Germany.

\section{Conclusions}

This paper provides a first exploratory analysis of the relation between sources of finance and investment activities of a prominent sector of the financial system, venture 
capital. It is of particular interest in light of the role that this sector is thought to perform in the development of new, high-technology enterprises and in view of the roles financial institutions play in the development of the VC industry.

We document substantial variations in the VC industries across countries. In some countries, they perform the function with which they are most commonly associated, namely, supporting companies in their initial stages of development. In others, they do not - they are more involved in later stage developments and management buyouts and buy-ins. In some countries, they raise finance from equity related institutions such as pension funds and life insurance companies, but in most they are funded from banks. Individuals and corporations also play an important financing function in some countries.

The national characteristics of VC industries in the four countries of this study are not closely related to the traditional distinctions between bank and market oriented financial systems. In many respects, there is a greater similarity between Germany and the United Kingdom than between Germany and Japan, in particular, in terms of stage of investment, sector and the importance of institutional funding. The large stock market economy of the United Kingdom is also associated with less early-stage investment than Israel.

The variations in financing and investment activities are related. Bank-backed funds are more heavily focused on late-stage investments, individual and corporate-backed funds on early stage. This is not readily attributable to the liquidity requirements of institutions because we do not observe a simple relation between the maturity structure of funding institutions and the investments of VC firms. For example, pension funds and insurancebacked funds do not have a particular early-stage focus, despite the long-term liabilities of their funding institutions. Instead, a more relevant distinction is between institutional investors, who display an aversion to investing in early-stage activities, and corporate and individual investors who are more actively involved in early-stage investments.

These relations differ across countries but again, not along simple financial system lines. The association of late-stage investment with financial institutions and early-stage investment with corporate and individual investors is more in evidence in Germany and the United Kingdom than in Japan and Israel. The relation of geographical focus with sources of finance is more pronounced in Germany than elsewhere. Thus, at least as far as the four countries in our sample are concerned, neither the overall patterns of investment nor the relations between sources of finance and activities suggest that international differences in VC activities are attributable to the commonly used classifications of financial systems. In particular, there is no consistent evidence that financial institutions invest in higher risk, early-stage investments in bank-oriented economies. Furthermore, financial considerations only account for a small proportion of total cross-country and within-country variations in VC activities. Most of the cross-country variation is associated with the country dummies, which could proxy for a variety of factors (e.g., the availability of investment projects, alternative sources of finance for innovative activity, the degree to which innovative activities are performed within rather than outside large firms, tax incentives, legal differences, and macroeconomic conditions). We do not attempt to identify these factors here; however, the significance of the country dummies suggests that factors other than the sources of finance may be important in understanding the pronounced variations in the VC industries of Germany, Israel, Japan and the United Kingdom. 


\section{Acknowledgements}

We thank Hedva Ber, Marco Da Rin, Michel Habib, Thomas Hellman, Eugene Kandel, Ken Kim, Jan-Peter Krahnen, Saul Lach, Sophie Manigart, Alan Morrison, Seki Obata, Kristian Rydqvist, Juro Teranishi, Naoyuki Yoshino, the editor, David Denis, and an anonymous referee of this journal for helpful comments and suggestions. We have also benefited from comments by seminar participants at the Bergen School of Management, the European Central Bank, the Oslo School of Management, the University of Oxford and Waseda University, and from participants at the CEPR Conference "Understanding Financial Architecture" (Madrid), the IMF/Hitotsubashi Conference on "Designing Financial Systems in East Asia and Japan" (Tokyo), the Mannheim Conference on "Industrial Economics and Input Markets," the NBER 2002 Japanese Economy Workshop (Tokyo) and the Yale Conference on Entrepreneurship. Financial support from the European Commission Research Training Network "Understanding Financial Architecture: Legal and Political Frameworks and Economic Efficiency" is gratefully acknowledged. This research project was initiated while Koen Schoors and Yishay Yafeh were visiting fellows at the University of Oxford (Saïd Business School; and St. Antony's College and the Nissan Institute, respectively) whose hospitality and financial support are gratefully acknowledged.

\section{Appendix A. Data sources}

All the data are snapshots at one particular point in time, the year 2000 for Germany, Israel and the United Kingdom and 1999 for Japan. For Germany and the United Kingdom, we mainly draw on data from their respective national venture capital associations, the "Mitglieder" database on http://www.bvk-ev.de/ for Germany and the "Directory Search" database on http://www.bvca.co.uk/ for the United Kingdom. This is complemented with information from the European association of venture capitalists (evca.com) for a small number of funds that show up in the European database, but not in their respective national ones. For Israel, we use the IVC-Online database provided by the Israeli association of venture capital on ivc-online.com. For Japan we rely on a survey conducted by Nikkei Kinyu (Financial Nikkei), 1999, on venture capital activities in Japan.

For Germany, Israel and the United Kingdom, we have data on all VC funds included in the associations, although some funds do not fully disclose data on their sources of funds and investment activities. This is rare for the United Kingdom and Germany (only 4 and 13 funds with incomplete data, respectively), but more common in the Israeli data (where data are incomplete for about 50 funds). Our database includes 187 German funds, 119 from Israel and 140 from the United Kingdom (in Israel only, there are multiple funds under the same management in the data). Note that membership of a particular country's $\mathrm{VC}$ association is open to funds operating in that country irrespective of where the fund is owned or controlled. For Japan, the Financial Nikkei survey provides information on 62 $\mathrm{VC}$ funds, about half of the extant population of $\mathrm{VC}$ funds in Japan according to this survey. 
Table A.1

Data availability in the four countries

\begin{tabular}{|c|c|c|c|c|}
\hline & Germany & Israel & Japan & $\begin{array}{l}\text { United } \\
\text { Kingdom }\end{array}$ \\
\hline Name/address/phone/fax/email & $\mathrm{x}$ & $\mathrm{x}$ & $\mathrm{x}$ & $\mathrm{x}$ \\
\hline Website & $\mathrm{x}$ & $\mathrm{x}$ & - & $\mathrm{x}$ \\
\hline Fund size & - & $\mathrm{x}$ & $\mathrm{x}$ & $\mathrm{x}$ \\
\hline Sources of funds (investors) & $\mathrm{x}$ & $\mathrm{x}$ & $x^{a}$ & $\mathrm{x}$ \\
\hline Portfolio size (number of companies) & - & $\mathrm{x}$ & $\mathrm{x}$ & $\mathrm{x}$ \\
\hline Minimum investment: & $x^{b}$ & $\mathrm{x}$ & - & $\mathrm{x}$ \\
\hline Maximum investment: & $x^{b}$ & $\mathrm{x}$ & - & $\mathrm{x}$ \\
\hline Average current investment size: & - & - & - & $\mathrm{x}$ \\
\hline Stage of investment: & $\mathrm{x}$ & $\mathrm{x}$ & $\mathrm{x}$ & $\mathrm{x}$ \\
\hline Industry preferences: & $\mathrm{x}$ & $\mathrm{x}$ & $\mathrm{x}$ & $\mathrm{x}$ \\
\hline Geographical preferences: & $\mathrm{x}$ & $\mathrm{x}$ & $\mathrm{x}$ & $\mathrm{x}$ \\
\hline Other subsidiaries & $\mathrm{x}$ & - & - & $\mathrm{x}$ \\
\hline Legal form ${ }^{c}$ & $\mathrm{x}$ & - & $\mathrm{x}$ & $\mathrm{x}$ \\
\hline Year of establishment & - & $\mathrm{x}$ & $\mathrm{x}$ & - \\
\hline Type of financing (equity, debt, convertible debt etc.) & $x^{d}$ & $\mathrm{x}$ & - & - \\
\hline
\end{tabular}

${ }^{a}$ For Japan, the owners because there are no other sources of finance.

${ }^{\mathrm{b}}$ For Germany, there is only a category "investment size", showing either minimum investment, maximum investment or both.

${ }^{\mathrm{c}}$ For Germany and sometimes the United Kingdom, indirect information through the name of the fund; for Japan, only stock companies.

${ }^{\mathrm{d}}$ Only equity subdivided into various types.

The data include management buyouts and buy-ins and leveraged recapitalizations. We do not distinguish between funds based on their ownership, but by their funding source. Thus, bank-backed refers to the source of financing (the limited partner in a US context), not to the ownership of the fund itself (the general partner), except for the case of Japan where owners are also the providers of finance.

Table A.1 shows the data availability for each country. The surveys supply information on more items than shown in the table, but only show items that are both relevant to our study and can be compared across countries are shown.

\section{Appendix B. Comparisons of Tables 1 and 2 with aggregate data on VC activity}

\section{B.1. Sources of funds}

For the United Kingdom and Germany, it is possible to compare the figures in Table 1 with aggregate statistics on sources of finance to VC and private equity (BVK, 2000). Aggregate figures differ somewhat from the figures in Table 1, because they are based on the amounts invested, not on whether a particular source is used. They also reflect a sizeweighted average of the sources used by individual funds, whereas our figures are simple averages. Finally, the aggregate statistics refer to private equity in general, rather than specifically to VC funds. Nevertheless, aggregate figures support our conclusions that 
banks are by far the most important source of finance for the German VC industry, providing about $40 \%$ of funds in 1999, far more than any other source.

In the United Kingdom, pension funds, banks and insurance companies, in this order, were the largest sources of finance in 1999 , providing $31 \%, 25 \%$, and $14 \%$ of the funds, respectively. Individual investors provided only $4 \%$ of the total amount of private equity raised in the United Kingdom in 1999. The significance of individual investors as a source of funds is greater in our data than in the aggregate figures, probably because they provide small amounts of money relative to other, institutional, sources of funds.

The figures in Table 1 are consistent also with those reported for Japan in 2000 by the Asian Venture Capital Journal (2002). According to these aggregate statistics, corporations (aggregating financial and other), banks and insurance companies were the most important sources of finance for the Japanese venture capital industry, providing $48 \%, 25 \%$, and $13 \%$ of all funds, respectively. By way of comparison, aggregate figures for the United States suggest that the most important sources of funds for the American VC industry in 1999 were pension funds, individuals, corporations, and insurance companies. These provided $23 \%, 22 \%, 15 \%$, and $13 \%$ of funds in the United States, respectively (NVCA, 2000).

\section{B.2. Investment Stage}

Panel A of Table 2 is consistent with evidence from other sources. Using aggregate data, EVCA (2000) reports that the distribution of investments for UK funds is centered on firms in middle stages of development, when measured by the number of companies in which investments are made. (In terms of amounts invested, there seems to be more weight on later stage investments involving $\mathrm{MBI} / \mathrm{MBO}$ activities.) Jeng and Wells (2000) report that investment in early stages relative to GDP has been slightly higher in Germany than in the United Kingdom in recent years, although in the past, the United Kingdom has invested relatively more in companies in their early stages. BVK (2000) provides figures that are consistent with these observations as well. IVA (2000) confirms our observation that VC investments in Israel are focused on early stages. Lerner and Hardymon (1999) describe the Japanese VC industry as focused on investment in much older firms than its American counterpart. Seed and startup investments accounted for only $17 \%$ of all VC investments in Japan in 1996, whereas expansion and "mezzanine" investment accounted for over 80\%. METI (2000) indicates that only a small fraction of the Japanese VC funds focus exclusively on early stages.

\section{B.3. Investment sector}

Data in Panel B of Table 2 are not easily comparable with available aggregate statistics because the industry classifications used differ between sources and because aggregate numbers are size-weighted averages, while our numbers are simple averages. Nevertheless, for Israel, IVA (2000) provides figures on VC investments by industries that are consistent with ours. For Germany and the United Kingdom, BVK (2000) confirms the relatively even spread of investments across sectors, with IT and manufacturing being important investment targets. Earlier figures for Japan are 
somewhat different from ours; Lerner and Hardymon (1999) report substantial VC investments in financial and other.services, as well as in (the not clearly defined) "consumer products". The Asian Venture Capital Journal (2002) figures are closer to ours in that they report substantial investment in services, but, like us, find that computer related investments constitute about $27 \%$ of the total amounts invested, far more than the life sciences and electronics sectors.

\section{B.4. Geographical focus}

The differences between the United Kingdom and Germany in Panel D of Table 2 are consistent with aggregate statistics from BVK (2000), which record that UK VC funds invest $25 \%$ of their capital abroad, compared with $15 \%$ invested abroad by German VC firms. Figures for Japan (as reported by the Asian Venture Capital Journal (2002)) suggest that investment outside Japan constituted $24 \%$ of total investment by Japanese VC funds in 2000 .

\section{References}

Allen, F., 1993. Stock markets and resource allocation. In: Mayer, C., Vives, X. (Eds.), Capital Markets and Financial Intermediation. Cambridge Univ. Press, Cambridge, pp. 81-108.

Allen, F., Gale, D., 1999. Diversity of opinion and financing of new technologies. Journal of Financial Intermediation 8, 68-89.

Allen, F., Gale, D., 2000. Comparing Financial Systems. MIT Press, Cambridge, Ma.

Bascha, A., Walz, U., 2001. Financing practices in the German venture capital industry: an empirical assessment, Unpublished manuscript, University of Tubingen.

Black, S., Gilson, R., 1998. Venture capital and the structure of capital markets: banks versus stock markets. Journal of Financial Economics 47, 243-277.

Bottazzi, L., Da Rin, M., 2002. Venture capital in Europe and the financing of European innovative firms. Economic Policy 17, 229-269.

Cornelli, F., Yosha, O., 2003. Stage financing and convertible debt. Review of Economic Studies 70, 1-32.

Cumming, D., 2001. United States venture capital financial contracting: evidence from investments in foreign securities, Unpublished manuscript, University of Alberta.

Gilson, R., Schizer, D., 2002. Understanding venture capital structure: a tax explanation for convertible preferred stock. Harvard Law Review 8, 878-916.

Gompers, P., Lerner, J., 1996. The use of covenants: an empirical analysis of venture partnership agreements. Journal of Law and Economics 39, 463-498.

Gompers, P., Lerner, J., 1998. What drives venture capital fundraising? Brookings Papers on Economic Activity (Microeconomics), 149-192.

Gompers, P., Lerner, J., 1999. The Venture Capital Cycle. MIT Press, Cambridge, Ma.

Gompers, P., Lerner, J., 2000. The determinants of corporate venture capital success: organizational structure, incentives, and complementarities. In: Morck, R. (Ed.), Concentrated Ownership. University of Chicago Press for the National Bureau of Economic Research, Chicago, pp. 17-50.

Gompers, P., Lerner, J., 2001. The venture capital revolution. Journal of Economic Perspectives 15, 145-168.

Hellman, T., 1998. The allocation of control rights in VC contracts. Rand Journal of Economics 29, 57-76.

Hellman, T., 2002. A theory of strategic venture investing. Journal of Financial Economics 62, 285-314.

Hellman, T., Puri, M., 2000. The interaction between product market and financing strategy: the role of venture capital. Review of Financial Studies 13, 959-984.

Hellman, T., Lindsay, L., and Puri, M., 2003. Building relationships early: banks in venture capital, Unpublished manuscript, Stanford University. 
Jeng, L., Wells, P., 2000. The determinants of venture capital funding: evidence across countries. Journal of Corporate Finance 6, 241-289.

Kaplan, S., Stromberg, P., 2003. Financial contracting theory meets the real world: an empirical analysis of venture capital contracts. Review of Economic Studies 70, 281-316.

Lerner, J., Hardymon, F., 1999. Venture Capital and Private Equity: A Case Book. Wiley, New York.

Lerner, J., Kortum, S., 2000. Assessing the contribution of venture capital to innovation. Rand Journal of Economics 31, 674-692.

Manigart, S., Sapienza, H., 2000. Venture capital and growth. In: Sexton, D., Landstrom, H. (Eds.), The Blackwell Handbook of Entrepreneurship. Blackwell, Oxford, Ch. 2.

Sako, M., Kelly, W., 2002. Governance of start-ups in Japan: what scope for change? Unpublished manuscript. Said Business School, Oxford.

Winton, A., 2003. Institutional liquidity needs and the structure of monitored finance. Review of Financial Studies $16,1273-1313$.

\section{Data Sources}

Asian Venture Capital Journal, 2002. The 2002 Guide to Venture Capital in Asia. Hong Kong. Available on the Internet at asiaventure.com.

BVK, 2000. Venture Capital in Europe, 1999. German Venture Capital Association, Berlin.

EVCA, 2000. Mid-Year Survey, January - June 2000. European Venture Capital Association. Brussels. Available on the Internet at http://www.evca.com.

IVA, 2000. 2000 Yearbook. Israel Venture Capital Association, Tel Aviv.

METI, Japanese Ministry of Economy, Trade and Industry, 2000. 2000 Yearbook on Japanese Venture Capital Investment. Thomson Financial/Venture Economics, Newark New Jersey.

Nikkei Venture Business Nenkan, 2001. Nikkei Annual Corporation Reports of Business, Nihon Keizai Shinbunsha, Tokyo.

Nikkei Kinyu, 1999. Venture Capital Chosa. Venture Capital Survey, Venture Club, Tokyo.

NVCA, 2000. NVCA Yearbook 2000. National Venture Capital Association, Arlington, VA.

OECD, 2003 Venture Capital Policy Review: Israel. Science, Technology and Industry OECD, Paris. Working Paper 2003/3. 